\title{
Farklılıkların Yönetiminin İşletmelerin Rekabet Stratejileri Üzerindeki Etkisine Yönelik Bir Araştırma ${ }^{1}$
}

\author{
DOI: 10.26466/opus.584547
}

\author{
Tuğba İmadoğlu* - Murat Türk** \\ * Dok. Öğr., Osmaniye Korkut Ata Üniversitesi, İ.İ.B.F / Osmaniye / Türkiye \\ E-Posta: tugba-imadoglu@hotmail.com ORCID: 0000-0002-4202-4495 \\ ** Prof. Dr., Osmaniye Korkut Ata Üniversitesi İ.I.B.F / Osmaniye / Türkiye \\ E-Posta: muratturk@osmaniye.edu.tr ORCID: 0000-0001-7040-4180
}

$\ddot{O} z$

Günümüzde işletmeler, oldukça zor ve farklı bir rekabet arenasıyla karşı karşıyadır. Rekabetin yapısı ve niteliğinde yaşanan birtakım değişimler, işletmelerin farklı yetenek ve özellikleri barındırmalarını gerektirmektedir. Yaşanılan çağda, bu değişimlerden sonra işletmeler, bünyelerindeki çalışanların farklı yetenek ve becerilerinden faydalandı̆̆ı sürece başarılı olabileceklerdir. Bu bağlamda bünyelerinde farklı özelliklere sahip çalışanlar bulunmaktadır. Böylece işletmeler rekabet ortamında hayatta kalabilecek ve rakipleri karşısında rekabet avantajı să̆layabileceklerdir. Bu çalışmada, Türkiye için öneminin giderek arttığ farklılıkların yönetiminin işletmelerin rekabet stratejileri üzerindeki etkisine dair 183 KOBİ çalışanının algıları incelenmiştir. Nicel araştırma deseni kapsamında gerçekleştirilen çalışmada kolayda örnekleme yöntemi ve online anket aracılığıyla veri toplanmıştır ve analizleri yapılmıştır. Analizler sonucunda farklılıkların yönetimi boyutlarından bireysel tutum ve davranışlar ile örgütsel değerler ve normların rekabet stratejilerini açıklamada pozitif yönlü katkı yaparken yönetsel uygulamalar ile politikalar boyutunun negatif yönlü katkı yaptığı belirlenmiştir.

Anahtar Kelimeler: Farklılık, Farklılıkların yönetimi, Rekabet stratejileri

\footnotetext{
${ }^{1}$ Bu makale, 18. Uluslararası Işletmecilik Kongresi'nde (2-4 Mayıs, 2019) sunulmuş olan bildirinin genişletilmiş halidir.
} 


\title{
A Research on The Effect of Management of Differences on Competition Strategies of Businesses
}

\begin{abstract}
Today, businesses encounter a rather difficult and diverse competition arena. Some changes in structure and quality of competition require businesses to have different abilities and characteristics. After these changes, the businesses will be able to succeed as long as they benefit from different abilities and skills of their employees. In this context, they have employees with different characteristics. Thus, businesses will be able to survive in a competitive environment and gain competitive advantage against their competitors. In this study, perceptions of $183 \mathrm{KOBI}$ employees were investigated related to the impact of management of differences which is becoming increasingly important in Turkey on competitive strategies of businesses. In the study which was carried out within the scope of quantitative research design, data were collected and analyzed by sampling method and online survey. As a result of the analyzes, it has been determined that individual attitudes and behaviors which are dimensions of management of differences and organizational values and norms make a positive contribution in explaining competitive strategies while dimension of managerial practices and policies make a negative contribution.
\end{abstract}

Keywords: Difference, Management of differences, Competition strategies. 


\section{Giriş}

Küreselleşen dünyada sosyal, ekonomik, teknolojik, politik hayatta birtakım değişimler yaşanmaktadır. Bu değişimler, işletmelerin kültürlerini ve stratejilerini etkilemektedir (Memduhoğlu ve Yılmaz, 2017). Bu süreçte hizmet ve üretimin en değerli varlığı olan insan kaynağının etkili ve verimli olarak yönetimi çok önemli bir hale gelmiştir (Fettahlığlu ve Tatlı, 2015). İşletmelerin rakipleri karşısında rekabet üstünlügü sağlaması için çalışanların farklı kabiliyetlerinden faydalanabilmesi gereklidir. Çalışanların cinsiyet, yaş, dil, din, ırk, engellilik vb. sahip oldukları farklılıklar, işletmelerin amaç ve hedeflerine katkıda bulunmaktadır (Sürgevil ve Budak, 2008). Bu nedenle işletmeler açısından ortalamanın üzerinde getiri elde etmek amacıyla işletme içerisinde ortaya çıkan farklılıkların doğru şekilde ve zamanında yönetilmesi önem arz etmektedir (Usta ve Bayraktar, 2017). Farklılıkların etkin olarak yönetilmesi işletmelerin büyümesini ve gelişmesini sağlayacaktır.

İlk olarak Amerika'da ortaya çıkan farklılıkların yönetimi kavramı, hızla Kanada ve Avustralya'da, daha sonra 1990'da Avrupa Birliği'nde kabul görüp uygulanmaya başlanmıştır. Böylece önemli bir yönetsel uygulama olmuştur (Tozkoparan ve Vatansever, 2011). Farklılıkların yönetimi, çalışanların farklılıklarıyla işletmelerde yer edinmesi konusunda kabul görmüş bir yaklaşımdır. Yani işletme içindeki farklılıkların ayrımında olup, bu farklılıkları işletme yararına kullanmayı amaçlayan ve gelecek odaklı şekilde stratejik düşünce sahibi, karşılıklı iletişimi kuvvetli insan kaynağını etkinleştirme olarak tanımlanmaktadır (Keil vd., 2007). Başka bir tanıma göre farklılıkların yönetimi, kurum içerisindeki çalışanların kendi yeteneklerinin farkına vararak, bu yetenekleri kullanacak ortamın yaratılmasıdır (Duman, 2013).

Değişken dünyada ayakta kalabilmek ve geleceğe yönelik planlar oluşturabilmek için işletmelerin rekabet stratejilerini geliştirmeleri ve geliştirilen bu stratejileri günümüz koşullarına göre uyarlayıp şekillendirmeleri gerekmektedir (Demirhan, 2002). Bu bağlamda rekabet güçleri artabilecektir ve başarıyı yakalayabileceklerdir. İşletmeler, rekabet güçleri ve örgütsel yetenekleri oranında ayakta kalabilmektedir. Rekabetli hayat biçimine uyum sağlayabilen işletmeler devamlılık kazanabilmektedir. İşletmelerde rekabet gücünün oluşturularak geliştirilmesi ve bu gücün 
sürdürülebilir kılınması bakımından üretim maliyeti, teknoloji, AR-GE faaliyetleri, kalite standartlarına uygunluk, nitelikli işgücü, pazar payı, ürün kalitesi ve çeşitliliğinin arttırılması gibi farklı faktörlerin etkin yönetilmesi önemlidir (Kayabaşı, 2007). İşletmeler, içinde barındırdığı bu farklılıklara değer vererek, farklı gruplarda faaliyet gösterenlerin sahip oldukları değerli varlıkların farkında olmalı ve bu farklılıkları kullanma odaklı olmalıdırlar (Taşlıyan, Hırlak ve Çiftçi, 2016).

İşletmelerin sürdürülebilir rekabet üstünlüğü sağlaması açısından önemli etki yaratabilecek kavramlardan biri de farklılıkların yönetimidir. $\mathrm{Bu}$ çalışma, farklılıkların yönetiminin işletmelerin rekabet stratejileri üzerindeki etkisine yönelik firma çalışanlarının algılarını ölçmek amacıyla yapılmıştır. İki kavramın bir arada kullanılmasıyla yapılan ilk çalışma olması nedeniyle literatüre önemli katkısı olacağı düşünülmektedir.

\section{Literatür Taraması}

\section{Farklılık Kavramı}

Her kültürün birbirinden farklılıkları vardır. Bu farklılıklar, işletmelerin çalışma şekillerini ve yönetim tarzlarını etkilemektedir. Bu bağlamda farklılıkları neticesinde birtakım sorunlar ortaya çıkabilmektedir (Duman, 2013). Bu tür sorunları çözüme kavuşturmak için de kendileri sıkıntıya düşmektedirler. Yöneticiler sorunlara yeni ve yaratıcı yaklaşımlar getirebilmek için astlarının bireyselliğini ortaya çıkarmayı hedeflemektedirler (Schmidt ve Tannenbaum, 1960).

Farklılık üzerinde çeşitli yorumlar yapılabilmektedir. Bu nedenle önce bu kavramın ne anlama geldiği açılanmalıdır (Hubbard, 2004). Farklılık, kurumsal amaçları gerçekleştirmek adına uygulanmaktadır. Farklılıklar ve benzerlikler ile bütünleştirilen bir birleşimi ifade etmektedir (Duman, 2013). İnsanlar arasındaki ırk, kültür, cinsiyet, cinsel tercih, fiziksel yeterlilikler, etnik köken, ulusal köken, din, öğrenme, iletişim biçimi, doğum yeri ve meslek gibi kavramlar farklılık olarak tanımlanmaktadır (Sürgevil, 2008). Başka bir deyişle bir insanı diğerinden ayıran bireysel farklılıkları ortaya çıkaran kavram farklılık olarak adlandırılmaktadır (Duman, 2013). Cinsiyet ve dil farklılı̆̆ insanın doğumundan itibaren vardır. Bunların 
yanı sıra etnik, kültürel ve irksal farkl1lıklar da bulunmaktadır (Arrendondo, 1996). İnsanlık tarihinin başlangıcından itibaren var olan farklılık her zaman olmaya devam edecektir.

Kirton ve Greene (2005), kurumlardaki farklılık ve eşitlik uygulamalarını çeşitli kategorilere ayırmıştır. Bu kategoriler şunlardır (Gröschl, 2011):

- Negatif Kurumlar: Bu tür kurumlar için farklılıktan herhangi bir fayda sağlayamadığı söylenebilir. Ayrıca birtakım farklılık politikaları vardır. Kurum içinde bilinçli veya bilinçsiz olarak ayrımcılık yapilabilir.

- Kısmi Kurumlar: Farklılık konusunda tüm çalışanlara eşit hak tanınmıştır. Farklılık konusunda olumlu bir görüş bulunmaktadır; ancak farklılık kavramını etkileyecek herhangi bir girişimleri veya uygulamaları bulunmamaktadır.

- Uyumlu Kurumlar: Girişimler ve uygulamalar yasal çerçeveler şeklinde gerçekleşmektedir. Bunun yanı sıra kişi haricinde grubun performansı daha çok dikkate alınmaktadır.

- Kapsayıc Proaktif Kurumlar: Bu tür kurumlar, sadece işyerindeki farklılıkları dikkate almakla yetinmemektedir. Çalışanlara eşit davranılmaktadır ve ayrımcilık yapmamaktadır. Hangi durumlarda verimliliğin sağlanacağı ve arttırılacağı konularılyla ilgilenmektedir.

\section{Farklılıkların Faydalar}

İnsanların yeni yönetim şekli arayışları farklılıkları beraberinde getirmiştir (Yıldızoğlu, 1996). Farklılıkların varlığı yöneticinin işini birçok yönden zorlamaktadır. Yönetici, bu farklılıkları etkili şekilde ele almak istemektedir. Bu nedenle farklılıkların etkin kılınması için bir yeteneğin ortaya çıkarılması ve etkin olması gerekmektedir (Schmindt vd., 1960).

Etkin bir farklılık yönetiminde yöneticilerin birtakım fayda beklentileri bulunmaktadır. Bu beklentiler içerisinde, çalışanlar arasında etkinliğin sağlanması ve iletişimin arttırılması, sosyal ve demografik değişimlere cevap verme, kurum içi ve dışı şikayetlerin en aza indirgenmesi, sorunların hızlı şekilde çözüme kavuşturulması, adaletli bir ortamın oluşturulması ve eşitliğin sağlanması, satış ve buna paralel olarak gelirlerde artış 
olması yer almaktadır (Bergen vd., 2002). Farklılıkları yönetmenin faydaları şu şekilde sıralanmaktadır (Duman, 2013):

- Personel seçimini büyük bir yetenek havuzundan yapmayı sağlar.

- İşgücü devrinin ve işe devamsızlığın yarattığı maliyetleri azaltır.

- Çalışan esnekliğini arttırır ve duyarlılığ geliştirir.

- Çalışan bağlılığını ve moralini artırır. Böylece çalışanların istekli şekilde çabalamalarını sağlar.

- Küreselleşmenin ve teknolojik değişim ve gelişmelerin etkilerinin daha iyi bir şekilde yönetilmesini sağlar.

- Yenilik ve yaratıcılığı artırır.

- Farklı kültürlerin nasıl işlediğine dair bilgilendirir.

- Müşterilerin talep ve ihtiyaçlarını anlamayı ve buna dair çalışmalarda bulunmayı sağlar.

- Yeni ürünlerin, hizmetlerin ve pazarlama stratejilerinin geliştirilmesinde destek pozisyonunda olur.

- Dışarıdaki sosyal paydaşlara karşı, kurumun itibarını ve imajını arttırir.

- Dezavantajlı gruplar açısından bir fırsattır. Sosyal uyumun sağlanmasına katkısı vardır.

\section{Farklılıkların Sakıncaları}

Kurumlarda işgücü bazı boyutlarda farklılık göstermektedir. Dil, ekonomik sistemin algılanması gibi faktörlerin temel kültürel değerler açısından oldukça homojen olduğu söylenebilir. Ancak uluslararası kurumlarda başta dil ve iletişim farklılıkları bulunmaktadır. Ayrıca yönetim tarzlarının belirlenmesini sağlayan kültürel farklılıklar, hiyerarşiye karşı tavır, ekip çalışmasına bakış açısı ve kararlara katılım gibi temel farklılıklar da olabilmektedir (Duman, 2013). Farklılığın sakıncaları şu şekilde sıralanabilir:

Bağlılık: Grupların arasında var olan bağl1lı̆̆ farklılıktır. Çünkü insanlar duygu ve davranış bakımından kendilerine benzer insanlarla daha rahat ve uyumlu çalışmaktadırlar. Grup bağlılığının olması çalışanları işlerine odaklanmalarını ve işlerinde performanslarının artmasını sağlamaktadır (Duman, 2013). 
Baskın Grubun Morali: Kurumlar içerisinde sadece kadın veya erkekleri ya da azınlık grupları destekleyici programlar yapıldığında kurumdaki baskın grup kendilerine eşit şekilde davranılmadığını düşünebilir. Bu bağlamda kurumda bir gerilim yaşanabilir. Buna ek olarak da baskın grubun moralinde bir düşüş ortaya çıkabilir (Durman, 2013).

İletişim: Değişimlere uğrayan insanoğlunun varlığını devam ettirme şeklinin bir ürünüdür. Kurumda farklı yapıda insanların olması iletişim sorununu ortaya çıkarmaktadır. Bu nedenle kurum içindeki iletişim yavaşlamaktadır (Duman, 2013).

\section{Farklılıkların Yönetimi}

Kişiler, eşsiz, benzersiz, birbirinden bağımsız ve farklıdırlar (Memduhoğlu ve Akyürek, 2014). Farklı özellikteki çalışanların bir arada olduğu işletmelerde etkili, verimli ve kaliteli kararların ortaya çıkmasını amaçlayan anlayış farklılık yönetimi olarak adlandırılmaktadır (Thomas, 2010). Farklikların yönetimi kavramı, kurumsal performansa gözle görünür şekilde katkı yapan, destekleme, planlama ve yönetme sürecidir. Farklılığın yönetimi, farklılığın etkilerini anlayarak bu etkilere cevap verecek davranışları, iş uygulamaları ve politikalarını uygulamaktır (Duman, 2013).

Farklılıklar, kişileri birbirinden farklılaştıran ya da onları birbirine benzer kılan bireye özgü içsel ve dişsal tüm özelliklerdir. Bireyler arasında dil, din, ırk, cinsiyet, yaş, kültür vb. birçok farklılık bulunmaktadır (Atasoy, 2012). Bazen de bireyler karşılıklı olarak istenen bir hedefe ulaşma olasılıkları, prosedürleri, stratejileri veya taktikleri hakkında farklılık göstermektedir (Tannenbaum vd., 2013). Bu farklılikların ülke ve toplumlar bakımından kendine has önem seviyeleri bulunmaktadır (Lauring, 2013). Örnek vermek gerekirse ABD ve İngiltere'de işgücü farklılıkları olarak cinsiyet, ırk, din, yaş, engellilik durumu, göçmenlik statüsü, sosyal sınıf, medeni durum, çocuk sahibi olup olmama, cinsel yönelim gibi konular yer alırken; Hindistan'da kast yapısı, etnisite, din ve cinsiyet bu farklılıklar arasında yer almaktadır. Çin'de ise yaş, cinsiyet, engellilik durumu, köylü-şehirli ayrımı sosyal farklılıkların temel nedenidir (Cooke ve 
Saini, 2012). Tozkoparan ve Vatansever (2011)'e göre Türkiye'de ise bireylerin kendisinden farklı gördüklerine tahammülleri oldukça sınırlıdır. Bu farklılıklar iyi yönetildiğinde işgücü için potansiyel faydalar ortaya çıkarmaktadır. Böylece maliyetlerde azalmalar olmaktadır, pazarlama imkanları artmaktadır, yaratıcılıklar gelişmektedir ve problem çözmede kolaylık sağlamaktadır (Sürgevil, 2010). Farklılıkları yönetmek, işgören farklılıklarını ve benzerliklerini önemli görerek oluşacak potansiyellerin hepsini, işletmenin stratejik amaç ve hedeflerine katkı sağlamaktır (İnce vd., 2015).

Farklılıkların varlığı yöneticinin işini pek çok açıdan karmaşık hale getireceğinden dolayı, farklılıkları tam olarak anlaması ve etkili bir şekilde ele almayı öğrenmesi son derece önemlidir (Schmidt vd., 1960). Farklılık yönetimi ile farklılığın faydaları en üst düzeye çıkacaktır ve kurumsal sistemlerin sorunları ve sakıncaları en alt düzeye inecektir. (Duman, 2013). $\mathrm{Bu}$ nedenle farklılıkların etkin şekilde yönetilmesi zorunluluğu ortaya çıkmaktadır. Farklılık yönetiminin etkin yönetilmesi için örgütsel gelişimin sağlanması ve kültür değişikliği uygulamalarının yapılması gerekmektedir (Allen ve Montgomery, 2001). Farkl1lı̆̆ın etkin yönetilmesi konusunda çalışanların herkese eşit davranıldığına inanmaları gerekmektedir. Bu açıdan yöneticilerin uygulamaları oldukça samimi bir şekilde yürütmeleri ve yürüttüğüne dair çalışanları inandırmaları şarttır (Tozkoparan vd., 2011). Sosyal ve iş çevrelerinde git gide farklılıkların artması işletmeleri zorlamadığı için bu farklılıkları anlayarak hareket etmek ge-reklidir (Usta ve Bayraktar, 2017). Farklılık yönetimi kavramını bir süreç olarak kullanan Hubbard (2004), bu sürecin önemli faktörleri olarak çeşitliliği planlamayı, organize etmeyi, yönetmeyi ve desteklemeyi sıralamıştır. Buna ek olarak birçok araştırmacı farklılık yönetimini devam ettirilebilir ve kontrolü sağlanabilir bir süreç olarak ele almıştır (Kurtulmuş, 2016). Farkl1lıkların yönetimi faaliyetlerinin sistemli ve planlı bir şekilde uygulanması, bu doğrultuda büyük önem arz etmektedir (Tozkoparan vd., 2011). Ancak Maldonado, Dreachslin, Dansky, Souza ve Gatto (2002) ise kontrol etmek yerine değer çeşitliliğini ve benzerliklerini vurgulamıştır. 
Tablo 1. Farklılıkların Yönetimi ve İlişkili Alanlara Ait Değerler Listesi (Özan ve Polat, 2013, s.58)

\begin{tabular}{|c|c|c|}
\hline $\begin{array}{l}\text { Farklılıkların } \\
\text { Yönetimi Alanı }\end{array}$ & Farklılık Alanı & $\begin{array}{l}\text { Örgüt ve İnsan } \\
\text { Sistemleri Gelişim Alanı }\end{array}$ \\
\hline $\begin{array}{l}\text {-Bireysel } \\
\text { farklılıklara saygı } \\
\text {-Sosyal adalet } \\
\text {-Katılımcılık } \\
\text {-Ortaklaşalık } \\
\text {-Orjinallik } \\
\text {-Sevecenlik } \\
\text {-Öncü eylem ve tevazu } \\
\text {-Etkinlik ve sağlık } \\
\text {-Yaşam boyu öğrenme }\end{array}$ & $\begin{array}{l}\text { Global Değerler } \\
\text {-Adalet ve tarafsızlık } \\
\text {-Sayg1/Empati/Sorumluluk } \\
\text {-Aile/Toplum ilişkileri } \\
\text {-Dürüstlük/Ruhanilik } \\
\text {-Öğrenme/Özgürlük } \\
\text { İş Değerleri } \\
\text {-Yenilikçilik/Durumsallık } \\
\text {-Hizmet alanların memnuni- } \\
\text { yeti } \\
\text {-Kalite/Üretkenlik/Yararlılık }\end{array}$ & $\begin{array}{l}\text {-Yaşam ve mutluluk arayışı } \\
\text {-Öz-kontrol/Sorumluluk } \\
\text {-Adalet/Özgürlük } \\
\text {-İnsan potansiyelini güçlen- } \\
\text { dirme } \\
\text {-Saygi/Temel haklar } \\
\text {-Açıklık/Kabul/Dürüstlük } \\
\text {-Esneklik/Değişim/Etkinlik } \\
\text {-Ö̈ğrenme/Gelişme } \\
\text {-İşbirlikli/Kazanmacı Tutum } \\
\text {-Katılımcılık/Demokratiklik } \\
\text {-Etkililik }\end{array}$ \\
\hline
\end{tabular}

Tablo 1'e göre işletmelerde farklılıkların yönetimi alanına ilişkin verilen ortak değerler bulunmaktadır. Bu ortak değerler, bütün işletme ve insan sistemlerinin gelişim alanlarında bulunan değerlerle ilgilidir. $\mathrm{Bu}$ bakımdan ortak değerlerin özellikle farklılıkların yönetimini işletmelerinde uygulamayı düşünen yöneticiler tarafından iyi anlaşılması gereklidir. Ayrıca bu değerlere dayalı çalışan katılımı sağlanmalıdır (Boydak ve Polat, 2013).

\section{Farklılıklarn Yönetiminin Uygulanması}

İnsanların geneli kendi fikir ve görüşlerine benzerlik gösteren insanlarla daha iyi, kolay ve hızlı bir iletişim kurmaktadırlar (Atasoy, 2012). İşletme çalışanları arasında etkin bir iletişim ağının oluşturulması gereklidir. Bu durumda işletme yöneticilerinin işletme içi etkili iletişimin sağlanmasına dair tutum ve davranışları önemlidir (Gökçen ve Çavuş, 2014). Herhangi bir konuda yanlış anlaşılmaların olması, bazı konularda çatışmaların yaşanması gibi durumlar çok az olmaktadır (Atasoy, 2012). Ancak çalışanlar iletişim kurmada sıkıntı yaşıyorsa, ekip çalışmasına yatkın değilse ve kendi kendini etkin şekilde yönetemiyorsa bu durum işletmelerin de farklılıkları iyi yönetemediğini göstermektedir (Özgener, 2009). 
İşletmelerde farklılıklar olması kaçınılmazdır; çünkü çalışanlar birbirinden farklı özelliklere ve niteliklere sahip bireylerdir. Bu nedenle işletmelerde farklılık ve farklılıkların verimli yönetimi kavramları dikkate alınması gereken bir husustur. Dikkate alınmadığı takdirde işletmelerin amaç ve hedefleri gerçekleştirmesini zorlayıcı bir güç haline gelir. Bu bağlamda farklı özelliklere sahip çalışanlar bu ortak amaç ve hedefler doğrultusunda ne kadar bütünleştirilebilirse başarı da o derece hızlı olacaktır (Ergül ve Kurtulmuş, 2014). İşletmeler farklılık yönetiminin faydaları olduğunu bilirler ve anlarlarsa bu anlayışı uygulama alanı olarak kullanabilirler. Bu açıdan bakıldığında farklılıkların yönetiminin görünen faydalı etkilerini gösteren uygulamalara performans, işletme karlılığı ve verimlilik gibi işletmenin çıtıları arasındaki var olan ilişkiyi gösteren çalışmaların ortaya konulması gereklidir. Bunun sonucunda işletmeler farklılıkların yönetiminin önemini anlayabilirler (Sürgevil, 2010). Farkl1lıkların yönetimi ile ilgili faaliyetleri bünyelerinde uygulayan işletmeler, bu uygulamaların rakipleri karşısında rekabetçi üstünlük sağladığının farkındadırlar. İşletmeler ayrıca bilgilerin işlenmesi, problem çözme ve karar verme süreçlerinde birtakım gelişmelerin olmasını da sağladığının bilincindedirler (Atasoy, 2012).

İşletmeler, farklılıkları doğru ve etkin şekilde değerlendirip kullandıkları zaman olumlu şekilde sonuçlarını göreceklerdir (Giffin ve Moorhead, 2010). Farklılıklar, işletmelerin problem çözme kapasitelerini arttırarak yeni fikirleri öne sürme ve oluşan veya oluşabilecek sorunlara çözümler üretme, yeni pazarların yolunu açma, farklı müşterilere daha iyi hizmet sağlama, müşterilerin ihtiyaç ve taleplerini karşılayabilme, kurumsal imajı arttırmada ve böylece rekabet avantajı sağlamada işletmeler için önemli bir faktördür (Ergül vd., 2014).

İşletmelerin başarılarının artması ve rekabet üstünlüğü sağlamaları için yöneticilerin tüm işleri iyi organize etmesi, işletmenin amaçları ile yönetim politikalarını doğru belirleyip stratejik şekilde uygulamaları gereklidir (Begeç, 2004). İşletmelerin farklılıkların yönetimiyle ilgili stratejilerinin olması, farklı işgücüne sahip olmanın avantajlarını bildiklerini, çalışanlarının farklılıklarından yararlandıklarını ve müşterilerinin talep ettiklerinin neler olduğunu daha iyi anladıklarını göstermektedir (Atasoy, 2012). 


\section{Farklılı Yönetiminin İşletmelerin Rekabet Stratejilerine Etkisi}

İşletmeler, faaliyetlerini güçlü bir şekilde etkileyen ve onları uluslararası pazarlarda rekabet etmeye zorlayan şiddetli küresel rekabetle karşı karşıyadırlar (Kumlu, 2014). İşletmeler ekonomik sermayelerini ne kadar etkin kullansalar da farklılık yönetimini doğru şekilde uygulayamazlarsa sürdürülebilir rekabet üstünlügünü sağlayamayacaklardır. Bu nedenle küreselleşme ve teknolojik değişimler ölçüsünde işletmeyi rakiplerinden ayıracak farklılıkları, etkin ve verimli şekilde işletme içinde uygulamaları gerekmektedir. İnce (2006)'ye göre rekabetin hizla arttığ1 rekabet dünyasında işletmeler, güçlü şirket felsefeleri ve stratejileri olan, bağımsız düşünerek faaliyetleri uygulayan çalışanları sayesinde ayakta kalabilmektedirler.

\section{Rekabet ve Rekabet Stratejisi Kavramlan}

Günümüz piyasasında rekabet olgusunun etkileri giderek daha da artmaktadır (Tekin ve Çiçek, 2005). İşletmelerin varlıklarını devam ettirmenin koşulu, rakipleri karşısında farklılıklar yaratmak, stratejileri hızlı ve doğru şekilde hayata geçirebilmektir. Rekabet, işletme ve müşterilerin varlıklarını sürdürebilmeleri bakımından gereklidir. İşletmelerin maliyet avantajının olması, değer yaratabilmesi ya da her ikisini yapabilmesi rekabet üstünlüğü elde etmesini sağlamaktadır (Gümüş, 2009). Bono (1996)'ya göre rekabetin amacı, maliyetleri düşük ve kaliteyi yüksek tutarak müşterilere fayda sağlamaktır. Rekabet, ülke, işletme, grup ya da kişisel bakımdan farklı amaçları olmaları nedeniyle farklı şekillerde algılanan, farklı yetenekleri ve yönetimi gerektiren bir kavramdır (Kayabaş1, 2007). Ülgen ve Mirze (2004)'nin tanımına göre rekabet, bir yandan müşterilerin ihtiyaçlarını karşılarken, diğer yandan müşteri istek ile taleplerinin karşılanmasını sağlayan ve müşteriler için fark etkisi oluşturan stratejilerle piyasada mücadele etmektir. İşletmeler rakiplere göre daha iyi bir performans göstererek, uzun dönemli üstün rekabetçi pozisyon sağlamayı başarmak rekabet stratejisi olarak adlandırılmaktadır. Böylelikle işletmenin pazardaki büyümesi uzun bir dönem için garantilenmiş olur. Buradaki amaç, müşterilerin algıladığı kriter ve nitelikleri öneme alan rekabet avantajları yaratmaktır (Muslu, 2015). 
Bir işletmenin aynı alandaki rakiplerine oranla daha üstün performans sergilemesini sağlayan özellikleri rekabet üstünlüğü olarak adlandırılmaktadır. Bu bağlamda bir işletme, rakiplerine göre büyük oranda değer yaratarak rekabette üstünlük sağlayabilir. Bir işletmenin değer yaratma açısından gerekli faaliyetleri rakiplerinden daha az maliyetle ya da daha kaliteli, verimli yapmasıyla ilişkilidir. Bir işletmenin rakipleri karşısında rekabet üstünlüğü sağlayacak şekilde sistematik ve birbiriyle alakalı kararlar seti olan rekabet stratejilerinin başarıyla uygulanabilmesi için iki şartın sağlanması gerekmektedir. Bunlar (Alayoğlu, 2010):

- İşletme, stratejileri uygulayacak varlıklara, yeteneklere ve becerilere sahip olmalıdır,

- Hangi tür stratejinin hangi şartlarda daha yüksek bir başarıyla çalışacağının farkında olmalıdır.

Rekabet stratejisini açıklamadan önce strateji kavramını açıklamada fayda vardır. Bir işletmenin stratejisi birçok farklı şekilde tanımlanmış ve benimsenmiştir. Bu durum çeşitli kuruluşların farklı ortamlardaki davranışlarına ve bu örgütler üzerindeki çevrenin çeşitli etkilerinden kaynaklanmaktadır (Kubon ve Krasnodebski, 2010). Strateji, işletmeye yön vermek ve rekabette üstünlük sağlamak için, işletme ve çevresini devamlı analiz ederek uyum sağlayacak amaçların saptanması, faaliyetlerin planlı şekilde oluşturulması, faaliyetler bakımından gerek duyulan araç ve kaynakların planlara göre tekrar düzenlenmesi olarak tanımlanmaktadır (Dinçer, 1998). Başka bir tanıma göre strateji, rakiplerin faaliyetlerini de araştırarak, amaçlara ulaşmak adına saptanmış, nihai sonuca odaklanmış, uzun dönemli, dinamik kararlar topluluğudur (Ülgen ve Mirze, 2004).

Strateji kavramının tanımlanmasında üç önemli husus önemlidir. Bunlar (Alayoğlu, 2010):

- Uzun vadeli bir hedefin belirlenmesi,

- Bu hedefe ulaşmak amacıyla çevresel (iç ve dış) şartlarla alakalı olarak yapılması düşünülen değişiklikler karşısında izlenecek yolların sürekli gözden geçirilmesi ve yenilenmesi

- Belirlenen bu yollara ilişkin dinamik nitelikte kararların alınması ve uygulanmasi.

Rekabet stratejilerinin kapsamı içinde rakiplerle nasıl rekabet mücadelesi halinde olunacağı, bu mücadelenin nasıl devam ettirileceği, 
hangi şekilde davranışsal özelliklerle mücadelenin kazanılacağı gibi durumlarla alakalı bilgiler ve tasarımlar yer almaktadır (Engin, 2005). İşletmelerin başarılarında ve büyümesinde rekabet stratejileri önemli bir paya sahiptir. Rekabet stratejisi, bir sektörde devamlı faaliyette bulunmak amacıyla, beş rekabet gücünün (yeni girenlerin tehdidi, alıcıların pazarlık gücü, ikame ürün ve hizmetlerin tehdidi, tedarikçilerin tehdidi ve mevcut işletmeler arasındaki rekabet) etkisiyle işletmenin yatırımlarını artırmak adına saldirgan ve savunmacı faaliyetlerde bulunması olarak tanımlanmaktadır. Rekabet stratejileri, işletmenin yönetsel, fonksiyonel ve işlemsel olarak saptanmış amaçlarına ulaşabilmesi adına gereklilik arz etmektedir. Rekabet stratejisinin yanıt aradığı birtakım sorular vardır. Bunlar (Kayabaşı, 2007):

- Belirli bir ürünün pazarında ya da sektör içerisinde en iyi olarak nasil rekabet edilebilir?

- Var olan pazar payında artış olması ya da devam ettirilmesi nasıl sağlanabilir?

- Uzun ve kısa vadeli hedefler neler olmalıdır?

- Saptanan hedeflere nasıl ulaşılabilir?

Rekabet stratejilerini etkili ve verimli kullanan işletmeler rekabet üstünlüğü elde etmiş olurlar. Rekabet üstünlüğü, işletmelerin müşterileri için rakiplerine göre daha büyük oranda değer yaratmasıyla yakından ilişkilidir. Bu durum ise, işletmenin hedeflenen ve amaçlanan faaliyetleri için rakiplerinden daha az maliyetle ve daha kaliteli şekilde yapmasından kaynaklanır (Porter, 1985).

\section{Rekabet Gücünü Belirleyen Faktörler}

Bireylerin beceri ve yeteneklerini geliştirmeleri küreselleşen dünyada işletmelerin rekabet gücü üzerinde önemli derecede etkilidir. Rekabetin ortaya çıkması maliyetlerin etkin olmasını, düşük fiyatları, sürekli gelişimi ve yeniliğe her daim açı olmayı gerektirmektedir (Kayabaşı, 2007). İşletmelerde rekabet gücünün geliştirilmesi ve sürdürülebilir rekabet üstünlüğü sağlanması bakımından etkili olan 7 faktör bulunmaktadır. Bunlar; üretim maliyeti, teknoloji ve ar-ge faaliyetleri, kalite ve standartlara uygunluk, nitelikli işgücü, pazar payı, ürün kalitesi ve çeşitliliğinin arttırılması, diğer faktörlerdir (Kayabaşı, 2007). 
Üretim Maliyeti: Rekabet gücünü belirlemede temel faktördür. Üretim maliyetleri arasında hammadde ve malzemeler, yardımcı malzemeler, işçilik giderleri önem arz etmektedir. Ürünlerin belli bir maliyet düzeyinde ve kalite standartlarına uygun olması gereklidir. Bu durum ise maliyetleri azaltacak çalışmalar ile yöntemlerin uygulanması ile mümkündür. Böylece maliyetlerde bir azalma olacaktır, yapısal ve sistematik değişimleri de yakından takip edip bunları uygulayan işletmeler rakipleri karşısında fiyat avantajı sağlayacaklardır (İpekgil Doğan vd., 2003).

Teknoloji ve Ar-Ge Faaliyetleri: Teknoloji, işletmelerin önceden belirlenmiş birtakım amaçlarına ulaşmada, oluşan sorunların uygun şekilde çözümünde, gözleme dayalı olarak ve kesinliği belirlenmiş bilgilerin uygulanması olarak tanımlanmaktadır. Hoban (1965)'a göre ise yönetim, süreç, düşünceler, makine ve insan organizasyonlarının entegre olduğu bir yapıdır. Rekabetin her geçen gün arttığı günümüz koşullarında işletmeler başarılı olmak istiyorlarsa rakiplerine oranla daha kaliteli mal ve hizmet üretebilmesi için gerekli olan teknolojik yapılanmayı oluşturmalıdırlar. Rekabet sıralamasında üst sıralarda yer alan işletmeler incelendiğinde arge faaliyetlerini etkili kullandıkları ve önem verdikleri görülmektedir (Kayabaşı, 2007).

Kalite Standartlarna Uygunluk: Müşteri talep ve beklentileri sürekli değişim göstermektedir. Bu nedenle işletmelerin kalite anlayışı doğrultusunda uluslararası kalite standartlarına uygun şekilde uygulamaları yapmaları gerekmektedir. Bu bağlamda rakipleri karşısında rekabet güçlerinde artış olacaktır. AB ve EFTA (Avrupa Serbest Ticaret Birliği) üyesi ülkeler, faaliyetler konusunda üreticilerin kusursuz olmasını ve bu durumu belgelemesi zorunluluğunu getirmiştir. Ayrıca yayınladıkları ISO 9000 kalite standartları serisine göre aranan şartları ve bu şartların yerine getirilmesi amacıyla gerekli olan yönetim sisteminin nasıl ve ne şekilde kurulabileceğini, belgelendirmenin nasıl yapılacağını ve devamlılığın nasıl sağlanacağını göstermektedir (İpekgil Doğan vd., 2003).

Nitelikli İşgücü: Rekabet gücünü ön plana çıkaran faktörlerden bir diğeri de çalışanların nitelikli bilgi, beceri ve yeteneklere sahip olmalarıdır. Alanında uzman kişilerin görevlere getirilmesi faaliyetlerin daha hızlı ve 
güvenli şekillerde yapılmasını sağlamaktadır. Böylece işletmenin performansında bir artış görülebilecektir ve rekabet gücü de artacaktır (Kayabaşı, 2007).

Pazar Payı: İşletmeler iç ve dış pazar paylarına sahiptir. Bu nedenle hazır bir müşteri kitlesi bulunmaktadır. Mevcut pazarının var olması işletmelerin eline geçen bilgiler, strateji, plan ve politikaların saptanması, var olan pazarın korunması ve daha da genişletilmesi bakımından rekabet gücü oluşturmaktadır (Kayabaşı, 2007).

Ürün Kalitesi ve Çeşitliliğinin Arttırılması: Ürünlerin kalitesini bozmadan işletmenin mevcut kapasitesinden en üst seviyede faydalanarak ürünleri farklılaştırmak, ürün çeşitliliği oluşturmak, maliyet ve kalite iyileştirmeleri yapmak rekabet gücünü arttırmaktadır (Uzay, 2005).

Diğer Faktörler: Bahsedilen 6 faktör dişında etkinlik, verimlilik, etkililik, alt yapı ve pazara yakınlık durumları, devlet yardımlarının olması, yatırım yapabilme gücünün büyüklüğü, kapasitenin esnek olması, güvenilirliğin sağlanması, firma imajı ve markalaşmanın oluşturulması, satış sonrası hizmetlerin iyi bir şekilde sunulması, envanter yönetimi uygulamaları, üretimin doğru zamanda olması, teslimatta hızlı olunması, finansman olanaklarının arttırılması, uygulanması gereken yönetim yaklaşımı ve politikaları, dış pazar bilgisinin doğru şekilde elde edilmesi, müşteri ve çalışan memnuniyetinin sağlanması gibi faktörler rekabet gücünü etkileyen faktörlerdir (Kayabaşı, 2007).

\section{Rekabet Politikaları}

İşletmeler rekabet gücü elde etmek için birtakım politikalar geliştirmişlerdir. Geliştirilen politikalar ile müşteri portföyününü genişleterek müşteri değeri yaratılmaya çalışılmış ve müşteri ihtiyaç ve talepleri en hızlı şekilde karşılanmaya çalışılmıştır. Buna ek olarak pazar fırsatları oluşturulmaya çalışılmıştır. Çalışmalar esnasında politikalar doğrultusunda ortaya çıkabilecek fırsat ve tehditlerin belirlenmesi gereklidir. Böylece işletmenin oluşabilecek fırsatları en iyi ve doğru şekilde değerlendirebilmesi, muhtemel tehditlere karşı gereken önlemlerin 
alınması, var olan üstünlüklerin kullanılması ve zayıflıkların giderilmesi çalışmalarının yapılması sağlanmış olacaktır (Kayabaşı, 2007).

Rekabet politikası uygulamaları arasında müşteri odaklılığının sağlanması, kaliteli ürün üretilmesi, esnekliğin oluşturulması, maliyetlerin azaltılması, yenilik ve tasarım konularında bilgi sahibi olunması, mikro ve makro olarak dinamik şekilde gerçekleştirilmeye çalışılan en iyi uygulamalar yer almaktadır. Buradaki amaç; işletme içindeki çalışanlar tarafından benimsenerek kalıcılığın ve gelişimin sağlanmasıdır. Rekabet politikaları etkili ve verimli şekilde uygulandığı zaman toplumsal refah sağlanacak ve işletmenin gelişiminde büyük adımlar atılmış olacaktır (Kayabaşı, 2007).

\section{Araştırma Metodolojisi}

\section{Araştırmanı Amacı ve Yöntemi}

Bu çalışma, farklılıkların yönetiminin işletmelerin performansı üzerindeki etkisine yönelik KOBİlerde alt seviye, orta seviye ve üst seviye çalışanlarının algılarını ölçmeyi amaçlamaktadır. Çalışma, nicel araştırma deseni kapsamında gerçekleştirilmiştir. Kolayda örnekleme yöntemi ve online anket tekniği kullanılmıştır. Online anket tekniğinin kullanılmasının nedeni birçok ildeki çalışanların da araştırmaya dahil edilmesi ve böylece araştırmanın daha geniş bir alanı kapsamasının sağlanmasıdır. Oluşturulan anket formu, İstanbul, Ankara, İzmir, Adana, Aydın, Hatay, Kahramanmaraş, Zonguldak, Mersin, Gaziantep ve Osmaniye illerinde KOBI'lerdeki 250 firma çalışanına gönderilmiştir. Bu çalışanlardan 183'ü anketi doldurarak geri dönüş yapmıştır. Öncelikle belirlenen işletmelere ve çalışanlara Facebook, Instegram, Whatsapp ve E-mail gibi sosyal medya araçları ile çalışmanın amacı açıklanmıştır. Araştırmaya katılmayı kabul eden çalışanlara daha sonradan yine sosyal medya araçları ile anket gönderilmiştir.

Araştırmada katılımcıların farklılıkların yönetimine ilişkin algılarını ölçmek üzere Balay ve Sağlam (2004) tarafından geliştirilen 30 ifade ve 3 boyuttan oluşan "Farklılıkların Yönetimi Ölçeği" kullanılmıştır. Ölçeğin boyutları bireysel tutum ve davranışlar (6 ifade), örgütsel değerler ve normlar (7 ifade), yönetsel uygulamalar ve politikalar (17 ifade) 
şeklindedir. Söz konusu ölçekte araştırmaya katılan çalışanların verilen ifadelere ilişkin algılarını belirlemek için (1) "Kesinlikle katılmıyorum", (5) "Kesinlikle katılıyorum" aralığında değişen 5'li Likert tipi derecelendirme ölçeğinden yararlanılmıştır. Rekabet stratejisine yönelik algıları ölçmek için Sümer (2012) tarafından oluşturulan ve yüksek lisans tezinden alınan 20 ifade ve 3 boyuttan oluşan "Rekabet Stratejisi Ölçeği" kullanılmıştır. Ölçeğin boyutları maliyet liderliği (6 ifade), farklılaştırma (9 ifade) ve odaklanma (5 ifade) şeklindedir. Bu ölçekte ise (1) "Çok az önemli", (5) "Çok önemli" aralığında değişen 5'li Likert tipi derecelendirme yapılmıştır.

Elde edilen bulgular analizler için hazır hale getirilmiştir. Bu amaçla kayıp değer, uç değer ve normal dağılım analizi yapılmıştır. Elde edilen verilerde ortak yöntem sapması probleminin olup olmadığı da incelenmiştir ve ölçeklerin içsel tutarlılıkların belirlemek amacıyla güvenilirlik düzeyleri hesaplanmıştır. Betimleyici istatistik analizi aracılı̆̆ıyla katılımcların araştırma değişkenlerine ilişkin düzeyleri ölçülmüştür. Farklılıkların yönetiminin ve rekabet stratejileri algısının eğitim düzeyi ve kurumdaki pozisyona göre anlamlı bir farklılık gösterip göstermediğini belirlemek için tek yönlü varyans analizi (anova) yapılmıştır. Farklılıkların yönetimi ve rekabet stratejileri arasındaki ilişkiler korelasyon analizi aracılığıyla incelenmiştir. Son olarak farklılıkların yönetiminin işletmelerin rekabet stratejileri üzerindeki açıklayıcılık (yordayıcılık) durumunu belirlemek amaciyla regresyon analizine tabi tutularak değerlendirilmiştir. Analizler SPSS 21 paket programı aracılığı ile yapılmıştır.

\section{Araştırmanın Örneklemi}

Örneklem grubuna ilişkin frekans dağılımlarında cinsiyet, yaş, eğitim düzeyi, medeni durum, kurumdaki pozisyon ve kurumdaki çalışma süresine ait altı farklı değişken kullanılmıştır. Söz konusu demografik özellikler Tablo 2'de görülmektedir.

Tablo 2'ye bakıldığında atılımcların 105 (\%57,4)'i kadın, 78 (\%42,6)'i erkek olduğu görülmektedir. Araştırmaya katılanların yaş aralığına bakıldığında \%41,0 oranla 25-29 arası yaş grubu en kalabalık yaş grubunu 
ve $\% 9,8$ oranla 20-24 arası yaş grubu en az olan yaş grubunu oluşturmaktadır. Katılımcıların eğitim düzeylerine bakıldığında en fazla oran olan \%58,5 (107 kişi)'inin lisans mezunu katılımcılara, en az oranın ise \%3,3 (6 kişi) ile ilkokul mezunu katılımcılara ait olduğu görülmektedir. Katılımcıların kurumdaki pozisyonlarına bakıldığında 119 kişinin $(\% 65,0)$ orta seviyede olduğu ve 19 kişinin $(\% 10,4)$ alt seviyede olduğu görülmektedir. Çalışanların kurumdaki çalışma sürelerine bakıldığında çalışma süresi 0-5 yıl arası olan katılımcılardan $100(\% 54,6)$ 'ünün en büyük paya ve 21 yıl ve üzeri olan katılımcılardan $6(\% 3,3)^{\prime}$ 'sının en az paya sahip olduğu görülmektedir.

Tablo 2. Katılımcılara Ait Demografik Özellikler

\begin{tabular}{|c|c|c|c|}
\hline \multicolumn{2}{|c|}{ Demografik değişkenler } & \multirow{2}{*}{$\begin{array}{l}\text { Frekans } \\
105\end{array}$} & \multirow{2}{*}{$\begin{array}{l}\text { Yüzde (\%) } \\
57,4\end{array}$} \\
\hline \multirow{3}{*}{ Cinsiyet } & Kadın & & \\
\hline & Erkek & 78 & 42,6 \\
\hline & Toplam & 183 & 100,0 \\
\hline \multirow{6}{*}{ Yaş } & $20-24$ aras1 & 18 & 9,8 \\
\hline & 25-29 arasi & 75 & 41,0 \\
\hline & $30-34$ aras1 & 33 & 18,0 \\
\hline & $35-39$ aras1 & 33 & 18,0 \\
\hline & 40 ve üzeri & 23 & 12,6 \\
\hline & Toplam & 183 & 100,0 \\
\hline \multirow{7}{*}{ Eğitim Düzeyi } & İlkokul & 6 & 3,3 \\
\hline & Ortaokul & 8 & 4,4 \\
\hline & Lise & 19 & 10,4 \\
\hline & Ön lisans & 23 & 12,6 \\
\hline & Lisans & 107 & 58,5 \\
\hline & Lisans üstü (Yüksek lisans+Doktora) & 20 & 10,9 \\
\hline & Toplam & 183 & 100,0 \\
\hline \multirow{3}{*}{ Medeni Durum } & Bekar & 85 & 46,4 \\
\hline & Evli & 98 & 53,6 \\
\hline & Toplam & 183 & 100,0 \\
\hline \multirow{4}{*}{$\begin{array}{l}\text { Kurumdaki } \\
\text { Pozisyon }\end{array}$} & Alt seviye & 19 & 10,4 \\
\hline & Orta seviye & 119 & 65,0 \\
\hline & Üst seviye & 45 & 24,6 \\
\hline & Toplam & 183 & 100,0 \\
\hline \multirow{6}{*}{$\begin{array}{l}\text { Kurumdaki } \\
\text { Çalışma Süresi }\end{array}$} & $0-5$ yıl & 100 & 54,6 \\
\hline & 6-10 yıl & 40 & 21,9 \\
\hline & $11-15$ yil & 26 & 14,2 \\
\hline & $16-20 \mathrm{yil}$ & 11 & 6,0 \\
\hline & 21 yıl ve üzeri & 6 & 3,3 \\
\hline & Toplam & 183 & 100,0 \\
\hline
\end{tabular}




\section{Araştırmanın Modeli ve Hipotezleri}

Bireysel tutum ve davranışlar, örgütsel norm ve değerler, yönetsel uygulamalar ve politikalar boyutlarından oluşan farklılıkların yönetiminin; rekabet stratejilerinin boyutları olan maliyet liderliği, farklılaştırma ve odaklanma üzerindeki etkisinin belirlemek üzere tasarlanan bu çalışmanın model olarak gösterimi aşağıdaki gibidir:

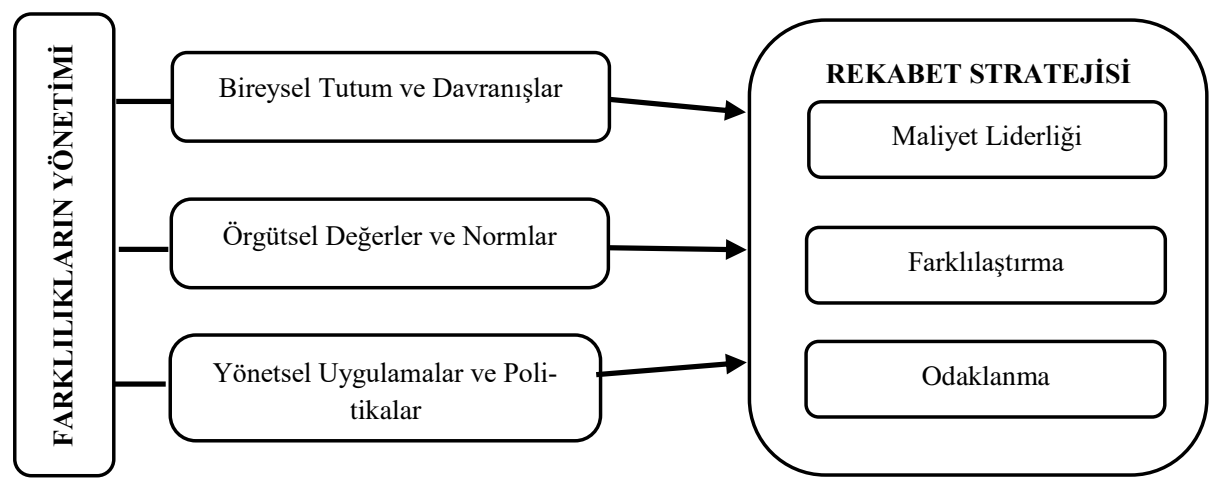

Şekil 1. Araştırmanın Modeli

Araştırmanın amacı ve modeli kapsamında geliştirilen hipotezler aşağıdaki gibidir:

- $\boldsymbol{H}_{1}$ : Farkliliklarm yönetimine ait bireysel tutum ve davranıslar boyutunun rekabet stratejisi üzerinde anlamlı bir etkisi vardır.

- $\quad \mathrm{H}_{2}$ : Farklılıklarm yönetimine ait örgütsel değerler ve normlar boyutunun rekabet stratejisi üzerinde anlamlı bir etkisi vardır.

- $\boldsymbol{H}_{3}$ : Farklulklarn yönetimine ait yönetsel uygulamalar ve politikalar boyutunun rekabet stratejisi üzerinde anlamlı bir etkisi vardır.

\section{Kayıp Değer, Uç Değer, Normal Dağılım Analizi}

Elde edilen verilerin analizlere hazır hale getirilmesi için ilk olarak kayıp değer analizi (missing value analysis) yapılmıştır. Yapılan analiz sonucunda kayıp değer olmadığı görülmüştür. Sonrasında uç değer (outliers) analizi yapılmıştır. Mahalanobis Uzaklığı (MU) Yöntemi kullanılarak 
yapılan uç değer analizinde $\mathrm{p}<.01$ anlamllık düzeyinde deneklerin merkezine uzak olan bir veri bulunmaması nedeniyle veri setinde uç değer olmadığı belirlenmiştir (Mahalanobis, 1936; Develi vd., 2018). Hesaplanan MU değeri, tablo değerinden küçük ise, çok değişkenli normallik varsayımının karşılandığı söylenebilir. $X^{2}$ tablo değerinin üzerinde bir MU değerine sahip olan denekler ise uç değerler olarak belirlenir ve verilerden çıkartılır (Koğar, 2010). Araştırmada kullanılacak analiz türlerinin (parametrik veya non-parametrik) belirlenebilmesi amaciyla elde edilen verilerin normal dağılım gösterip-göstermediğine bakılmıştır. Bu nedenle her bir ifadenin çarpıklık-basıklık (skewness-kurtosis) değerlerine bakılmıştır. Bulgulara göre en büyük çarpıklık değeri: 1.68, en büyük basıklık değeri: 2.95 'dir. Çarpıklık değerleri \pm 3 ve basıklık değerleri \pm 10 eşik değerlerinin içerisinde olduğundan dolayı verilerin normal dağılım gösterdiği sonucuna ulaşılmıştır (Kline, 2011; Develi vd., 2018, s.667). Bu nedenle araştırmada parametrik analizler kullanılmıştır.

\section{Bulgular}

\section{Geçerlilik Analizi}

Kullanılan ölçeklerin yapısal geçerliliğini belirlemek üzere yapılan açımlayıcı (keşfedici) faktör analizi kullanılmıştır. Faktör analizi yapılmadan önce, veri setinin faktör analizine uygun olup olmadığını belirlemek için Kaiser-Meyer-Olkin (KMO) testi ve Brtlett (Barlett's test of spherity) testi uygulanmıştır. Uygulanan KMO testine göre, 0,922 sonucu elde edilmiştir. Bu değerin 0,5'ten büyük olması, bize bu soruların faktör analizi uygulamaya elverişli olduğunu göstermektedir. Yapılan açımlayıcı (keşfedici) faktör analizinde araştırmada kullanılan iki ölçek aynı anda analize tabi tutulmuştur ve temel bileşenler analizi ile varimaks eksen döndürmesi tekniği kullanılmıştır. Maddelerden elde edilmek istenilen faktör sayısı bilindiği için fixed number of factor yöntemi seçilmiştir. Farklılıkların yönetimi ölçeğine ait ve rekabet stratejileri ölçeğine ait birer madde 0.50 'nin altında faktör yüküne sahip olması sebebiyle modelden çıkarılmıştır. Yeniden yapılan açımlayıcı faktör analizi sonucunda tüm değişkenlerin orijinal faktörlerine yüklendiği, faktörlerin toplam varyansın \%67.422'sini açıkladığı ve madde faktör yüklerinin 0.50'nin 
üzerinde olduğu tespit edilmiştir. Faktörlerin açıklama oranları farklılıkların yönetiminde \%54.518, rekabet stratejilerinde \%12.904 şeklindedir.

\section{Betimleyici İstatistik ve Güvenilirlik Analizi}

Araştırmada incelenen konular açısından örneklemin yapısını ortaya çıkarabilmek amacıyla betimleyici istatistik analizi yapılmıştır. İlgili sonuçlar Tablo 3'te görülmektedir. Betimleyici istatistik analizinin sonucundaki ortalama değerleri $(\overline{\mathbf{x}})$ dikkate alındığında firma çalışanlarının hem farklılıkların yönetimini algıladıkları $(\overline{\mathbf{x}}=3.37)$ hem de rekabet stratejileri algısına sahip oldukları $(\overline{\mathbf{x}}=3.96)$ görülmektedir. Çalışanların farklılıkların yönetimine dair en yüksek algı düzeyi bireysel tutum ve davranışlar $(\overline{\mathbf{x}}=3.44)$ iken örgütsel değerler ve normlar ile yönetsel uygulamalar ve politikaların da $(\overline{\mathbf{x}}=3.35)$ birbirine eşit olduğu ortaya çıkmıştır. Çalışanların rekabet stratejilerini hangi boyutuyla daha yüksek algıladıkları sırasıyla; farklılaştırma $(\overline{\mathbf{x}}=4.34)$, maliyet liderliği $(\overline{\mathbf{x}}=3.97)$ ve odaklanma $(\overline{\mathbf{x}}=3.25)$ şeklindedir.

Tablo 3. Betimleyici İstatistik ve Güvenilirlik Düzeyleri

\begin{tabular}{lllll}
\hline Ölçme Araçları ve Boyutları & $\overline{\mathbf{x}}$ & $\mathbf{s}$ & İfade Sayısı & $\boldsymbol{\alpha}$ \\
\hline Farklılıkların yönetimi & 3.37 & .83 & 30 & .97 \\
Bireysel tutum ve davranışlar & 3.44 & .94 & 6 & .88 \\
Örgütsel değerler ve normlar & 3.35 & .54 & 7 & .90 \\
Yönetsel uygulamalar ve & 3.35 & .16 & 17 & .96 \\
politikalar & & & & \\
Rekabet stratejileri & 3.96 & 1.04 & 20 & .90 \\
Maliyet liderliği & 3.97 & .81 & 6 & .81 \\
Farklılaştırma & 4.34 & .66 & 9 & .94 \\
Odaklanma & 3.25 & .87 & 5 & .80 \\
\hline
\end{tabular}

Not: $n=183, \bar{x}$ Örneklem ortalaması, s: Örneklem standart sapması, $\alpha$ : Cronbach's alfa katsayist

Ölçme araçlarının ve boyutlarının içsel tutarlılıklarını belirlemek amacıyla Cronbach's alfa $(\alpha)$ yöntemiyle güvenilirlik analizi yapılmıştır. Farklılıkların yönetimi ölçeğinin $(\alpha=.97)$ bireysel tutum ve davranışlar boyutuna ait alfa katsayısı $\alpha=.88$, örgütsel değerler ve normlar boyutuna ait alfa katsayısı $\alpha=.90$ ve yönetsel uygulamalar ve politikalar boyutuna 
ilişkin alfa katsayısı $\alpha=.96$ değerlerine sahiptir. Rekabet stratejileri ölçeğinin $(\alpha=.90)$ maliyet liderliği boyutuna ait alfa katsayısı $\alpha=.81$, farklılaştırma boyutuna ilişkin alfa katsayısı $\alpha=.94$ ve odaklanma boyutuna ait alfa katsayısı $\alpha=.80$ değerlerine sahiptir. Güvenilirlik analizi sonuçları incelendiğinde ölçeklere ait genel alfa katsayısı düzeyi literatürde genel kabul görmüş olan $\alpha \geq .70$ eşik değerinin üzerindedir (Nunnaly ve Bernstein, 1994). Bu değerlendirmelerden hareketle, tüm değişkenlere ait Cronbach's Alfa değerleri ölçeklerin içsel tutarlılıklarının güvenilir düzeyde var olduğunu göstermektedir.

\section{Tek Yönlü Varyans Analizi (Anova)}

Farklılıkların yönetiminin eğitim düzeyine göre anlamlı bir farklılık gösterip göstermediğini tespit etmek için tek yönlü varyans analizi (anova) yapılmıştır. Varyans analizi sonucuna göre farklılıkların yönetimi boyutlarının hepsinin algısının eğitim düzeyine göre \%1 anlamlılık düzeyinde istatistiki olarak anlamlı farklılık gösterdiği tespit edilmiştir.

Bireysel tutum ve davranışlar boyutunun eğitim düzeyinden hangisinde farklılaştığını tespit etmek için Post Hoc-Scheffe çoklu karşılaştırma testine başvurulmuştur. Post Hoc-Scheffe çoklu karşılaştırma testine göre bireysel tutum ve davranışlar algısının ilkokul, lise, ön lisans, lisan arasında \%1 anlamlılık düzeyinde farklılaştığı, ortaokul ve lisans üstünde farklılaşmadığı bulgusuna ulaşılmıştır. Ortalamalara bakıldığında ise bireysel tutum ve davranışlara ait lisans üstü (Ort.= 3.59), ön lisans (Ort.= 3.49), lisans (Ort.=3.46), lise (Ort.=3.06), ortaokul (Ort.=2.16) şeklindedir. Örgütsel değerler ve normlara ait en yüksek değerin sirasılyla lisans üstü $($ Ort.=3.50), lisans (Ort.=3.41), lise (Ort.=3.31), ön lisans (Ort.=3.10), ilkokul (Ort.=2.88) ve ortaokul (Ort.=2.21) olduğu görülmüştür. Yönetsel uygulamalar ve politikalara dair lisans üstü (Ort.= 3.53), ön lisans (Ort.= 3.51), lisans (Ort.= 3.40), ilkokul (Ort.= 3.19), lise (Ort.=3.07) ve ortaokul (Ort.= 2.36) olduğu görülmüştür.

Farklılıkların yönetimi algısının kurumdaki pozisyona göre anlamlı bir farklılık gösterip göstermediğini tespit etmek için tek yönlü varyans analizi (anova) yapılmıştır. Varyans analizi sonucuna göre farklılıkların yönetimi boyutlarından örgütsel değerler ve normlar ile yönetsel değerler ve 
uygulamalar algısının kurumdaki pozisyonlara göre \%1 anlamlılık düzeyinde istatistiki olarak anlamlı farklılık gösterdiği tespit edilmiştir.

Örgütsel değerler ve normlar ile yönetsel uygulamalar ve politikalar boyutunun kurumdaki pozisyona göre hangisinin farklılaştığını tespit etmek için Post Hoc-Scheffe çoklu karşılaştırma testi uygulanmıştır. Bu teste göre bireysel tutum ve davranışlar algısının alt seviye, orta seviye ve üst seviye arasında \%1 anlamlılık düzeyinde farklılaşmadı̆̆ 1 bulgusuna ulaşılmıştır. Ortalamalara bakıldığında ise örgütsel değerler ve normlara ait en yüksek değerin sirasıyla üst seviye (Ort.=3.45), alt seviye (Ort.=3.28) ve orta seviye (Ort.= 2.26) şeklindedir. Yönetsel uygulamalar ve politikalara dair en yüksek değerin sirasıyla üst seviye (Ort.=3.49), orta seviye (Ort.=3.30) ve alt seviye (Ort.=3.27) olduğu görülmüştür.

Rekabet stratejilerinin eğitim düzeyine göre anlamlı bir farklılık gösterip göstermediğini belirlemek için tek yönlü varyans analizi (anova) yapılmıştır. Varyans analizi sonucuna göre rekabet stratejileri boyutlarından maliyet liderliği ve farklılık algısının eğitim düzeyine göre \%1 anlamlılık düzeyinde istatistiki olarak anlamlı farklılık gösterdiği tespit edilmiştir.

Maliyet liderliği boyutunun hangi eğitim düzeyi arasında farklılaştığını belirlemek için Post Hoc-Scheffe çoklu karşılaştırma testine başvurulmuştur. Post Hoc-Scheffe çoklu karşılaştırma testine göre maliyet liderliği algisının ortaokul ve lise arasında \%1 anlamlılık düzeyinde farklılaştı̆̆ı, ilkokul, ön lisans, lisans ve lisans üstünde farklılaşmadığı bulgusuna ulaşılmıştır. Ortalamalara bakıldığında ise maliyet liderliğine ait lisans üstü (Ort.=4.13), lisans (Ort.=4.08), lise (Ort.=3.64), ilkokul (Ort.= 3.52), ön lisans (Ort.=3.50) ve ortaokul (Ort.=2.52) şeklindedir. Farklılık boyutuna ait en yüksek değerin sirasıyla lisans (Ort.=4.36), lisans üstü $($ Ort.= 4.35), ön lisans (Ort.= 4.02), lise (Ort.=3.87), ilkokul (Ort.=3.85) ve ortaokul (Ort.=2.80) olduğu görülmüştür. Rekabet stratejileri algısının kurumdaki pozisyona göre anlamlı bir farklılık gösterip göstermediğini belirlemek için tek yönlü varyans analizi (anova) yapılmıştır. Varyans analizi sonucuna göre rkabet stratejileri boyutlarından sadece maliyet liderliği algısının kurumdaki pozisyona göre \%1 anlamlılık düzeyinde istatistiki olarak anlamlı farklılık gösterdiği tespit edilmiştir. 
Maliyet liderliği boyutunun kurumdaki hangi pozisyona göre farklılaştığını tespit etmek için Post Hoc-Scheffe çoklu karşılaştırma testine başvurulmuştur. Post Hoc-Scheffe çoklu karşılaştırma testine göre maliyet liderliğinin üst seviye arasında \%1 anlamlılık düzeyinde farklılaştığı, alt seviye ve orta seviye arasında ise farklılaşmadığı bulgusuna ulaşılmıştır. Ortalama değerlerine bakıldığında maliyet liderliğine dair en yüksek değerin sirasıyla üst seviye (Ort.= 4.02), orta seviye (Ort.= 3.87) ve alt seviye (Ort.=3.64) olduğu görülmüştür.

\section{Pearson Korelasyon Analizi}

Araştırma modeli kapsamında; bireysel tutum ve davranışları, örgütsel değerler ve normlar, yönetsel uygulamalar ve politikalar değişkenleri ile rekabet stratejilerinin boyutları olan maliyet liderliği, farklılaştırma ve odaklanma değişkenlerinin değişme yönlerini ve şiddetlerini saptamak amacıyla Pearson korelasyon analizi yapılmıştır. Sonuçlar Tablo 4'te görülmektedir.

\section{Tablo 4. Pearson Korelasyon Analizi Sonuçları}

\begin{tabular}{llllllll}
\hline & Değişkenler & $\mathbf{1}$ & $\mathbf{2}$ & $\mathbf{3}$ & $\mathbf{4}$ & $\mathbf{5}$ & $\mathbf{6}$ \\
\hline $\mathbf{1}$ & Bireysel tutum ve davranışlar & 1 & & & & & \\
$\mathbf{2}$ & Örgütsel değerler ve normlar &, $85^{* *}$ & 1 & & & & \\
$\mathbf{3}$ & Yönetsel uygulamalar ve politikalar &, $75^{* *}$ &, $78^{* *}$ & 1 & & & \\
$\mathbf{4}$ & Maliyet liderliği &, $32^{* *}$ &, $33^{* *}$ &, $26^{* *}$ & 1 & & \\
$\mathbf{5}$ & Farklılaştırma &, 43 &, $38^{* *}$ &, $33^{* *}$ &, $71^{* *}$ & 1 & \\
$\mathbf{6}$ & Odaklanma &, 08 &, 11 &, 06 &, $36^{* *}$ &, $18^{*}$ & 1 \\
\hline
\end{tabular}

* işareti $p<.05$ anlamlllık düzeyini, ${ }^{* *}$ işareti $p<.01$ anlamlllık düzeyini göstermektedir.

Pearson korelasyon analizi sonuçlarına göre farklılıkların yönetimi boyutları ile ve rekabet stratejileri boyutları arasında istatistiksel olarak anlamlı ilişki bulunan ikili değişkenler şu şekildedir: bireysel tutum ve davranışlar ile maliyet liderliği $(\mathrm{r}=.32, \mathrm{p}<.01)$, örgütsel değerler ve normlar ile maliyet liderliği $(\mathrm{r}=.33, \mathrm{p}<.01)$, örgütsel değerler ile farklılaştırma $(\mathrm{r}=.38, \mathrm{p}<.01)$, yönetsel uygulamalar ve politikalar ile maliyet liderliği $(\mathrm{r}=.26, \mathrm{p}<.01)$, yönetsel uygulamalar ve politikalar ile farklılaştırma $(\mathrm{r}=.33, \mathrm{p}<.01)$, maliyet liderliği ile odaklanma $(\mathrm{r}=.36, \mathrm{p}<$ $.01)$, farklılaştırma ile odaklanma $(\mathrm{r}=.18, \mathrm{p}<.05)$ arasında anlamlı ve 
pozitif yönlü bir ilişki olduğu görülmektedir. Değişkenler arasında pozitif yönlü bir ilişkinin varlığı iki değişkenin birlikte değiştiğini göstermektedir. Bir başka ifadeyle çalışanların farklılıklarının yönetimi ile işletmelerin rekabet stratejileri birlikte artmakta veya azalmaktadır (Gürbüz ve Şahin, 2018:265). Farklılıkların yönetimi ile rekabet stratejileri ve boyutları arasındaki diğer ikili ilişkiler istatistiksel olarak anlamsızdır $(\mathrm{p}>.05)$.

\section{Çoklu Doğrusal Regresyon Analizi}

Araştırma modelinin bağımsız değişkenleri olan bireysel tutum ve davranışlar, örgütsel değerler ve normlar, yönetsel uygulamalar ve politikaların bağımlı değişkenler olan maliyet liderliği, farklılaştırma ve odaklanma üzerindeki açıklayıcılık (yordayıcılık) durumlarını saptamak için çoklu doğrusal regresyon analizi yapılmıştır. Sonuçlar Tablo 5'te görülmektedir.

Tablo 5. Çoklu Doğrusal Regresyon Analizi Sonuçları

\begin{tabular}{|c|c|c|c|c|c|c|c|c|c|}
\hline \multicolumn{2}{|c|}{ Bağımsız Değişkenler } & $\begin{array}{l}\text { Bağımlı } \\
\text { Değișkenler }\end{array}$ & $\beta$ & $\mathbf{r}$ & $\mathbf{R}^{2}$ & $\mathbf{F}$ & p & D-W & VIF \\
\hline \multirow{3}{*}{1} & $\begin{array}{l}\text { Bireysel tutum ve } \\
\text { davranışlar }\end{array}$ & \multirow{3}{*}{$\begin{array}{l}\text { Maliyet } \\
\text { liderliği }\end{array}$} & $.12^{*}$ & \multirow{3}{*}{.34} & \multirow{3}{*}{.11} & \multirow{3}{*}{1.958} & \multirow{3}{*}{.001} & \multirow{3}{*}{1.43} & \multirow{3}{*}{4.08} \\
\hline & $\begin{array}{l}\text { Örgütsel değerler ve } \\
\text { normlar }\end{array}$ & & $.19^{*}$ & & & & & & \\
\hline & $\begin{array}{l}\text { Yönetsel uygulama- } \\
\text { lar ve politikalar }\end{array}$ & & -.02 & & & & & & \\
\hline \multirow{3}{*}{2} & $\begin{array}{l}\text { Bireysel tutum ve } \\
\text { davranışlar }\end{array}$ & \multirow{3}{*}{$\begin{array}{l}\text { Farklılaş- } \\
\text { tırma }\end{array}$} & $.36^{*}$ & \multirow{3}{*}{.43} & \multirow{3}{*}{.19} & \multirow{3}{*}{2.683} & \multirow{3}{*}{.000} & \multirow{3}{*}{1.72} & \multirow{3}{*}{4.56} \\
\hline & $\begin{array}{l}\text { Örgütsel değerler ve } \\
\text { normlar }\end{array}$ & & .02 & & & & & & \\
\hline & $\begin{array}{l}\text { Yönetsel uygulama- } \\
\text { lar ve politikalar }\end{array}$ & & -.00 & & & & & & \\
\hline \multirow{3}{*}{3} & $\begin{array}{l}\text { Bireysel tutum ve } \\
\text { davranışlar }\end{array}$ & \multirow{3}{*}{ Odaklanma } & -.03 & \multirow{3}{*}{.12} & \multirow{3}{*}{.01} & \multirow{3}{*}{0.931} & \multirow{3}{*}{.629} & \multirow{3}{*}{1.43} & \multirow{3}{*}{2.81} \\
\hline & $\begin{array}{l}\text { Örgütsel değerler ve } \\
\text { normlar }\end{array}$ & & $.19^{*}$ & & & & & & \\
\hline & $\begin{array}{l}\text { Yönetsel uygulama- } \\
\text { lar ve } \\
\text { politikalar }\end{array}$ & & $-.06^{*}$ & & & & & & \\
\hline
\end{tabular}

Not: $\beta$ : Standardize edilmiş Beta katsayısı, $r$ : Korelasyon katsayısı, $R^{2}:$ Belirlilik katsayısı, $F: F$ testi istatistiği, p: İstatistiksel anlamlllık düzeyi, D-W: Durbin-Watson değeri, VIF: Varyans Artış Faktörü.

* işareti $p<.05$ anlamlllık düzeyini, ${ }^{* *}$ işareti $p<.01$ anlamlllık düzeyini göstermektedir. 
Modelde doğru sonuçlara ulaşabilmek amacıyla ölçme hataları ve hatalar arasındaki ilişkilere yönelik regresyon varsayımlarında sapmalar olup olmadığ 1 kontrol edilmiştir ve buna göre, tüm değişkenlerin DurbinWatson değeri (D-W) 2'den küçük olduğu için hata terimleri arasında ilişki olmadığ1 yani otokorelasyon probleminin olmadığı görülmüştür (Durbin ve Watson, 1971). Modelde çoklu doğrusal bağlantı araştırılmış ve bunun için Varyans Artış Faktörü (VIF) değerleri hesaplanmıştır. Tablo 5 incelendiğinde, VIF değerlerinin hepsinin 5 'ten küçük olduğu görülmektedir. Bu bağlamda çoklu doğrusal bağlantı sorununun olmadığı söylenerek hipotez kabul edilir (Dinç ve Yayar, 2017).

Birinci regresyon modelinde bağımsız değişkenler olan bireysel tutum ve davranışlar, örgütsel değerler ve normlar, yönetsel uygulamalar ve politikalar ile bağımlı değişken olan maliyet liderliği, farklılaştırma ve odaklanma arasında yapılan çoklu doğrusal regresyon analizinin sonuçları görülmektedir. $\mathrm{F}$ değeri $\% 1$ anlamlılık düzeyinde istatistiksel olarak anlamlıdır $[\mathrm{F}(3,179)=1.958, \mathrm{p}<.01]$. Yani maliyet liderliği değişkenini farklılıkların yönetimi ile tahmin etmek istatistiksel olarak mümkündür. Sonuçlara incelendiğinde; -1 ile +1 arasında değişen değerler alan korelasyon katsayısının bu modeldeki oranının $r=.34$ olduğu görülmektedir. Belirlilik katsayısı ise bağımsız değişkenlerin bu modelin \%11'ini açıkladığını göstermektedir $\left(\mathrm{R}^{2}=.11\right)$. Standardize edilmiş beta değerlerinden hareketle bu ilişkideki bağımsız değişkenlerin bağımlı değişkeni etkileme sırasına bakıldığında anlamlı etkinin bireysel tutum ve davranışlar $(\beta=.12)$ ile örgütsel değerler ve normlar olduğu görülmektedir ( $\beta=.19)$. Diğer bağımsız değişkenler, beta değerlerinin anlamsız olması sebebiyle bir etki göstermemiştir ( $\mathrm{p}>.05)$. Görülmektedir ki; bireysel tutum ve davranışlar ile örgütsel değerler ve normlar maliyet liderliğini açıklamada pozitif yönlü katkı yapmaktadır.

İkinci regresyon modelinde bağımsız değişkenler olan bireysel tutum ve davranışlar, örgütsel değerler ve normlar, yönetsel uygulamalar ve politikalar ile bağımlı değişken olan maliyet liderliği, farklılaştırma, odaklanma anlam boyutu arasında yapılan çoklu doğrusal regresyon analizinin sonuçları görülmektedir. F değeri \%1 anlamlılık düzeyinde istatistiksel olarak anlamlıdır $[\mathrm{F}(3,179)=2.683, \mathrm{p}<.01]$. Yani farklılaştırma boyutunu farklılıkların yönetimi ile tahmin etmek istatistiksel olarak mümkündür. Sonuçlara bakıldığında; -1 ile +1 arasında değişen değerler 
alan korelasyon katsayısının bu modeldeki oranının $\mathrm{r}=.43$ olduğu görülmektedir. Belirlilik katsayısı ise bağımsız değişkenlerin bu modelin \%19'ını açıkladığını göstermektedir $\left(\mathrm{R}^{2}=.19\right)$. Standardize edilmiş beta değerlerinden hareketle bu ilişkideki bağımsız değişkenlerin bağımlı değişkeni etkileme sırasına bakıldığında tek anlamlı etkinin bireysel tutum ve davranışlarda olduğu görülmektedir $(\beta=.36)$. Diğer bağımsız değişkenler, beta değerlerinin anlamsız olması sebebiyle bir etki göstermemiştir ( $p>$.05). Görülmektedir ki; bireysel tutum ve davranışlar rekabet stratejisinin farklılaştırma boyutunu açıklamada pozitif yönlü katkı yapmaktadır.

Üçüncü regresyon modelinde bağımsız değişkenler olan bireysel tutum ve davranışlar, örgütsel değerler ve normlar, yönetsel uygulamalar ve politikalar ile bağımlı değişken olan odaklanma boyutu arasında yapılan çoklu doğrusal regresyon analizinin sonuçları görülmektedir. F değeri \%5 anlamlılık düzeyinde istatistiksel olarak anlamsızdır $[\mathrm{F}(3,179)=$ 0.931, p > .05]. Yani rekabet stratejilerinin odaklanma boyutunu farklılıkların yönetimi ile tahmin etmek istatistiksel olarak mümkün değildir.

\section{Sonuç ve Öneriler}

Günümüzde işletmeler, yoğun bir rekabet ortamında hayatlarını sürdürebilmek amaciyla rakiplerinden farklılıklar yaratma ve en iyi şekilde bu farklılıkları yönetme yoluna gitmektedirler. Farklılıkların yönetimi konusu ülkemizdeki işletmeler bakımından yeni bir kavram olması nedeniyle bu konuda yapılmış çalışmalar sınırlıdır. Farklılıkların yönetiminin bu konudaki önemini anlayan işletmeler, bu konu üzerinde yoğunlaşmışlardır. Farklılık yönetimi faaliyetleri, işletmelerin rekabet güçlerine katkı yapmaktadır. İşletmeler, çalışanların farklı yetenek ve becerilerini uygun işlerde kullanarak etkin bir fayda sağlamaktadır. Böylece çalışan performansında bir artış gözlenmektedir. Çalışan performansındaki artış da aynı ölçüde işletme performansını arttırmaktadır. Bu açıdan işletmeler hedeflenen amaçları doğrultusunda kar oranlarını arttırabilmektedir.

$\mathrm{Bu}$ çalışmanın sonucuna göre, bireysel tutum ve davranışların, rekabet stratejisinin farklılaştırma boyutunu açıklamada pozitif yönlü katkı yapmakta olduğu ortaya çıkmıştır. Ayrıca bireysel tutum ve davranışlar ile 
örgütsel değerler ve normların maliyet liderliğini açıklamada pozitif yönlü katkı yaptığı sonucuna ulaşılmıştır. Rekabet stratejisinin odaklanma boyutunu açılamada, yönetsel uygulamalar ve politikalar negatif yönlü katkı yaparken, örgütsel değerler ve normlar pozitif yönlü katkı yapmaktadır. Ancak Sümer (2012)'in çalışmasında rekabet stratejilerinin işletme performansı üzerinde doğrudan bir etkisi olmamıştır. Rekabet stratejilerinin performansını inovasyon, kalite ve teslimatın etkilediği saptanmıştır. Buna ek olarak da üretim stratejileri olarak maliyet ve esnekliğin rekabet konusunda büyük bir farklılık yaratmadığı ve odaklanma stratejisinin performansı olumlu etkilemediği gözlenmiştir. Çalışmamızın sonucuna göre farklılıkların yönetimi ve rekabet stratejileri boyutları arasındaki ikili ilişkiler incelendiğinde bireysel tutum ve davranışlar ile maliyet liderliği, örgütsel değerler ve normlar ile maliyet liderliği, örgütsel değerler ile farklılaştırma, yönetsel uygulamalar ve politikalar ile maliyet liderliği, yönetsel uygulamalar ve politikalar ile farklılaştırma, maliyet liderliği ile odaklanma, farklılaştırma ile odaklanma arasında anlamlı ve pozitif yönlü bir ilişki olduğu; ancak bireysel tutum ve davranışlar ile farklılaştırma, bireysel tutum ve davranışlar ile odaklanma, örgütsel değerler ve normlar ile odaklanma, yönetsel uygulamalar ve politikalar ile odaklanma arasında bir ilişkinin olmadığ1 sonucuna ulaşılmıştır. Kurtulmuş (2016)'un çalışmasına göre de ortaöğretim kurumlarında görevli öğretmenlerin farklılıklara yönelik yaklaşım ve yönetsel uygulamalara yönelik algılarının iyi seviyede olduğu saptanmıştır. Ancak Balyer ve Gündüz (2010)'ün araştırmasında ise öğretmenlerin farklılıklara yönelik yönetsel uygulamalara yönelik algılarının orta seviyede olduğu belirlenmiştir.

Farklılık, diğerlerinden farklı olma, aynı olmama durumudur. Farklılıkların yönetimi ise işletmelerdeki yöneticilerin, işletme faydası için farklı özelliklere sahip insanların farklılıklarından maksimum faydayı elde etmesi ve etkin bir yönetim gerçekleştirmesidir. Farklılıkların etkin yönetilmesi, çalışanlar arasında sinerji yaratılması, çeşitli kaynak ve bilgi sağlama, maliyetlerin en aza indirilmesi, beklenen üzerinde kar sağlanması, hizmet ve ürün kalitesinde artış sağlama gibi durumlarda faydalı olacaktır. Farklılıkların etkin ve doğru şekilde yönetilmesi ile firma çalışanlarının işletmeye olan bağlılı̆̆1 artacaktır. Fettahlıoğlu ve Tatlı (2015)'nın çalışmasına göre de farklılıkların yönetiminin örgütsel bağl1lığ1 
olumlu yönde ve orta düzeyde etkilediği sonucuna ulaşılmıştır. Buna ek olarak Yilmaz ve Kurşun (2013)'un okullarda, Magoshi ve Chang (2009)' in işletmeler üzerinde uyguladığı araştırma sonuçları da aynı yönde olup farklılıkların yönetiminin örgütsel bağlılığın önemli bir belirleyici olduğunu göstermektedir. Bu çalışmalar genel olarak değerlendirildiğinde işletmede farklılıkların yönetimi konusunda yapılacak faaliyetlerin çalışanların işletmelerine olan bağlılığını olumlu yönde etkileyeceği söylenebilir.

Bazı işletmeler farklılıkları bir tehdit unsuru olarak görmektedir. $\mathrm{Bu}$ düşünceye sahip işletmeler başarısızlığa gitmektedir. Farklılıkları bir tehdit unsuru olarak değil de avantaj olarak gören işletmeler de bulunmaktadır. Farklılıkları fırsat olarak gören işletmeler, farklılıkların yönetiminin işletmeye farklı bakış açıları kattığının farkındadır. Kârı arttırıcı ve rekabet üstünlüğü sağlayıcı bir unsur olduğunun da farkındadırlar. Farklılıklar nedeniyle işletmede birtakım çatışmalar da oluşabilir. Burada önemli olan durum bu çatışma ortamını minimuma indirmek ve en az zararla bu işin içinden çıkabilmektir. Uzun bir süreçte çalışanların farklılıklarını işletme amaçları doğrultusunda geliştirilmesi ile farklılıkların yönetimi, maliyet olmaktan çıkıp varlık haline dönüşebilecektir.

Sonuç olarak küresel piyasaların ve rakiplerin git gide arttığ 1 bir ortamda işletmelerin üretim öncesi, üretim esnası ve üretim sonrası tüm süreçlerinde rakiplerine üstünlük sağlayacak rekabet üstünlüğü yaratmak için farklılıkları etkin yönetmeleri gereklidir. Ancak bu etkin yönetimi de rekabet stratejileriyle uyumlu şekilde yapmaları işletmenin fark yaratması açısından önemlidir. Böylece sağlanan rekabet üstünlüğü sürdürülebilir hale gelecektir. 


\title{
EXTENDED ABSTRACT
}

\section{A Research on The Effect of Management of Differences on Competition Strategies of Businesses}

\author{
Tuğba İmadoğlu - Murat Türk \\ Osmaniye Korkut Ata University
}

In recent years, it is necessary for employees to benefit from different capabilities in order to provide competitive advantage over their competitors (Sürgevil ve Budak, 2008). For this reason, it is important to manage the differences arising within the enterprise correctly and in a timely manner in order to gain above-average returns for the enterprises (Usta ve Bayraktar, 2017). One of the concepts that can have a significant impact in terms of providing sustainable competitive advantage is the management of differences. This study was conducted to measure the perceptions of firm employees towards the effect of management of differences on competition strategies of enterprises.

In order to survive in a changing world and to form plans for the future, enterprises should develop competitive strategies and, adapt and shape these developed strategies according to today's conditions (Demirhan, 2002). In this context, they will be able to increase their competitiveness and achieve success.

The study was conducted within the scope of quantitative research design. Convenience sampling method and online survey technique were used. The questionnaire was sent to 250 employees in Small and Medium Enterprises (SME) in Istanbul, Ankara, Izmir, Adana, Aydin, Hatay, Kahramanmaras, Zonguldak, Mersin, Gaziantep and Osmaniye. 183 of these employees returned the survey completed. The findings were prepared for the analysis. For this purpose, loss value, extreme value and normal distribution analysis were performed. The reliability levels were calculated to determine the internal consistency of the scales. Descriptive statistical analysis, one-way analysis of variance (ANOVA), correlation analysis and multiple linear regression analysis were conducted. 
According to the results of this study, it appeared that individual attitudes and behaviors contributes positively in explaining the differentiation dimension of competitive strategy. In addition, individual attitudes and behaviors and organizational values and norms contribute positively in explaining cost leadership. While administrative practices and policies contribute to the focusing dimension of competition strategy negatively, organizational values and norms contribute to this dimension positively. However, in the study of Sümer (2012), competition strategies did not have a direct impact on business performance. Innovation, quality and delivery have been found to affect the performance of competition strategies. In addition, it is observed that cost and flexibility as production strategies do not make a big difference in competition and focus strategy does not affect performance positively. According to Kurtulmuş's (2016) study, it was found that the perceptions of the teachers working in secondary education institutions towards differences and managerial practices were at a good level. However, in the Balyer and Gündüz's (2010) study, it was determined that teachers' perceptions of managerial practices towards differences were moderate.

As a result, in an environment where the size of global markets and the number of competitors are gradually increasing, companies need to manage differences effectively in order to create a competitive advantage that will provide superiority against their competitors in all processes before, during and after production. However, it is important to make this effective management in line with competition strategies to make a difference for the enterprise.

\section{Kaynakça / References}

Alayoğlu, N. (2010). Rekabet üstünlügü sağlamada insan kaynakları ve rekabet stratejileri uyumunun önemi. İstanbul Ticaret Üniversitesi Sosyal Bilimler Dergisi, 9(17), 27-49.

Allen, R. S. ve Montgomery K. A. (2001). Applying an organizational development approach to creating diversity. Organizational Dynamics, 30(2), 149-161.

Arrendondo, P. (1996). Successful diversity management mitiatives. California: Sace Publications. 
Atasoy, Z. (2012). Farklılıkların yönetimi: üniversite öğrencilerinin ayrımcllık algısının öğrenci başarı düzeyine etkisi üzerine bir araştırma. Yüksek Lisans Tezi, Karamanoğlu Mehmetbey Üniversitesi Sosyal Bilimler Enstitüsü, Karaman.

Balay, R. ve Sağlam, M. (2004). Eğitimde farklılıkların yönetimi ölçeğinin uygulanabilirliği. SDÜ Burdur Eğitim Fakültesi Dergisi, 5(8), 32-46.

Balyer, A. ve Gündüz, Y. (2010). Yönetici ve öğretmenlerin okullarında farklılıkların yönetimine ilişkin algılarının incelenmesi. Atatürk Ĕ̆itim Fakültesi Ĕ̆itim Bilimleri Dergisi, 32, 25-43.

Begeç, S. (2004). Farklılıkların yönetimi ve genelkurmay başkanlığı barış için ortaklık merkezinde yapılan bir araştırma. Doktora Tezi, Marmara Üniversitesi Sosyal Bilimler Enstitüsü İşletme Anabilim Dalı, İstanbul.

Bergen, C. W. V.., Soper, B. ve Foster, T. (2002). Unintended negative effects of diversity management. Public Personel Management, 31(2), 239-251.

Bono, E. D. (1996). Rekabetüstü, (O. Özel Çev.), İstanbul:Remzi Kitabevi,

Cooke, F. L. ve Saini, D. S. (2010). Diversity management in India: A study of organizations in different ownership forms and industrial sectors. Human Resource Management, 49(3), 477-500.

Demirhan, D. (2002). İşletmelerde stratejik bilgi sistemleri yönetimi ve rekabet üstünlüğü elde edilmesindeki rolü. Ege Akademik Bakış Ekonomi, İşletme, Uluslararası İlişkiler ve Siyaset Bilimi Dergisi, 2(2), 117-124.

Develi, A., Çavuş, M. F. ve Öz, B. (2018). Psikolojik personel güçlendirmeyi yöneticinin güç kaynaklarıyla açıklamak: Sağlık sektöründe bir araştırma. İşletme Araştırmaları Dergisi, 10(4), 661680.

Dinç, H. ve Yayar, R. (2017). Türkiye'de turizm gelirlerini belirleyen faktörlerin regresyon analizi. Social Science Studies, 5(4), 351-368.

Dinçer, Ö. (1998). Stratejik yönetim ve işletme politikası. İstanbul: Beta.

Duman, M. D. (2013). Farklllıların etkin yönetiminde kullanılan halkla ilişkiler stratejileri bir kamu kurumu olarak emniyet teşkilatı. Yüksek Lisans Tezi, Marmara Üniversitesi, Sosyal Bilimler Enstitüsü Halkla İlişkiler Anabilim Dalı, İstanbul. 
Durbın, J. ve Watson, G. S. (1971). Testing for serial correlation in least squares regression. III. Biometrika, 58(1), 1-19.

Engin, E. (2005). İşletmelerin uluslararası rekabet stratejileri ve uygulamalı bir araştırma. Yüksek Lisans Tezi, Trakya Üniversitesi Sosyal Bilimler Enstitüsü, Edirne.

Ergül, H. F. ve Kurtulmuş, M. (2014). Farklılıkların yönetimi ölçeğinin geçerlik ve güvenirlik çalışması. Dicle Üniversitesi Ziya Gökalp Eğitim Fakültesi Dergisi, 22, 298-312.

Fettahlıoğlu, Ö. O. ve Tatlı, H. S. (2015). Örgütsel bağl1lık ve farklılıkların yönetimi algılamaları arası ilişkilerin saptanmasında demografik farklılıklara yönelik inceleme. KSÜ Sosyal Bilimler Dergisi/KSU Journal of Social Sciences, 12(2), 119-140.

Giffin, R. W. ve Moorhead, G. (2010). Organizational behavior: Managing people and organizations. South Western: Cengage Lerning..

Gökçen, A. ve Çavuş, M. F. (2014). Farklılık yönetimiyle örgütlerde yabanclaşmanın önlenmesi: yazınsal derleme. Akademik Sosyal Araştırmalar Dergisi, 2(1), 525-533.

Gröschl, S. (2011). Diversity in The Workplace: Multidisciplinary and International Perspectives. Gower Publishing, Burlington.

Gümüş, Y. (2009). Lojistik faaliyetlerin rekabet stratejileri ve işletme kârı ile olan ilişkisi. Muhasebe ve Finansman Öğretim Üyerleri Bilim ve Arştırma Derneği (MUFAD) Muhasebe ve Finansman Dergisi, 41, 97113.

Gürbüz, S. ve Şahin, F. (2018). Sosyal bilimlerde araştırma yöntemleri. (5. Bsm.), Seçkin, Ankara.

Hoban, C. F. (1965). From theory to policy decision. aud.vis. Common. Rev. 13(2), 121-39.

Hubbard, E. E. (2004). The manager's pocket guide to diversity management. Amherst, Massachusetts: Harward Press (22) Inc. U.S and Canada.

İnce, M. (2006). Değişim olgusu ve örgütlerde insan kaynakları yönetiminin değişen fonksiyonları. Selçuk Üniversitesi Sosyal Bilimler Enstitüsü Dergisi, 14, 319-339.

İnce, M., Gül, H., Canda, H. ve Çakıcı, A. B. (2015). Örgütlerde sınırlandırıcı ya da sürükleyici güç olarak farklılıkların yönetimi. Gümüşhane Üniversitesi Sosyal Bilimler Elektronik Dergisi, 12, 292321. 
İpekgil-Doğan, Ö., Marangoz, M. ve Topoyan, M. (2003). İşletmelerin iç ve diş pazarlarda rekabet gücünü etkileyen faktörler ve bir uygulama. DEÜ SBE Dergisi, 5(2), 114-139.

Kayabaş1, A. (2007). İşletmelerin rekabet gücünün geliştirilmesinde lojistik faaliyetlerin performansının arttırlması: üretim işletmeleri üzerine bir uygulama. Doktora Tezi, Dokuz Eylül Üniversitesi Sosyal Bilimler Enstitüsü İşletme Anabilim Dalı, İzmir.

Keil, M., Amershi, B., Holmes, S., Jablonski, H., Lüthi, E., Matoba, K., Plett, A., Unruh, K. (2007). Farklılıkların yönetimi için eğitim el kitabı: Ayrımcllığın engellenmesi ve farklılıkların yönetimi eğitimi. 15.10.2018 tarihinde http://www.idm-diversity.org/files/EU0708-TrainingManual-tr.pdf adresinden erişilmiştir.

Koğar, H. (2010). Farklı örneklem büyüklüklerinde uç değerlerle baş etme yöntemlerinin puanların geçerlik ve güvenirlik kantları üzerindeki etkisi. Yüksek Lisans Tezi, Ankara Üniversitesi Eğitim Bilimleri Enstitüsü Ölçme ve Değerlendirme Anabilim Dalı, Ankara.

Kubon, M. ve Krasnodebsk1, A. (2010). Logistic costs in competitive strategies of enterprises. Agric. Econ.-czEch, 56(8), 397-402.

Kumlu, Ö. (2014). The effect of intangible resources and competitive strategies on the export performance of small and medium sized enterprises. Procedia-Social and Behavioral Sciences, 150, 24-34.

Kurtulmuş, M. (2016). The effect of diversity management on teachers organizational commitment and organizational citizenship behavior. Pegem Ĕ̆itim ve Öğretim Dergisi, 6(3), 277-302.

Laurıng, J. (2013). International diversity management: global ideals and local responses. British Journal of Management, 24, 211-224.

Mahalanobis, P. C. (1936). On the generalized distance in statistics. Proceedings of the National Institute of Sciences (Calcutta), 2, 49-55.

Magoshi, E. ve Chang, E. (2009). Diversity management and the effects on employees' organizational commitment: evidence from japan and korea. Journal of World Business, 44, 31-40.

Maldonado, R. W., Dreachslin, J. L., Dansky, K. H., Souza, G. D. ve Gatto, M. (2002). Racial/Ethnic diversity management and cultural competency: The case of pennsylvania hospitals. Journal of Healthcare Management, 47(2), 111-124. 
Memduhoğlu, H. B. ve Akyürek, O. (2014). Öğretmenlerin ve okul yöneticilerinin görüşlerine göre anaokullarında farklılıkların yönetimi. Eğitim Bilimleri Araştırmaları Dergisi, 4(1), 175-188.

Memduhoğlu, H. B. ve Yılmaz, K. (2017). Yönetimde yeni yaklaşımlar. Ankara: Pegem. ISBN 978-605-364-067-7, DOI 10.14527/9786053640677.

Muslu, A. (2015). Deniz turizminde rekabet stratejisi olarak ürün farklılaştırması. Turizm ve Araştırma Dergisi, 4(2), 28-46.

Nunnally, J. C. ve Bernstein, I. H. (1994). Psychometric theory, (3rd Eds.), New York: McGraw-Hill, Inc.

Özan, M. B. ve Polat, M. (2013). İlköğretim öğretmenlerinin farklılıkların yönetimine yönelik algıları:Muş ili örneği. E-International Journal of Educational Research, 4(4), 55-77.

Özgener, Ş. (2009). İş ahlakının temelleri. Ankara: Nobel Yayıncılık.

Porter, M. E. (1985). Competitive advantage: Creating and sustaining superior performance. New York: The Free Press.

Schmidt, W. H. ve Tannenbaum, R. (1960). Management of differences. Harvard Business Review.

Sümer, K. (2012). Rekabet stratejisinin ürerim stratejisine ve işletme performansına etkisi. Yüksek Lisans Tezi, İstanbul Teknik Üniversitesi Fen Bilimleri Enstitüsü, İstanbul.

Sürgevil, O. (2008). Farklılık kavramına ve farklılıkların yönetimine temel oluşturan sosyo-psikolojik kuramlar ve yaklaşımlar. Balıkesir Üniversitesi SBE Dergisi, 11(20), 111-124.

Sürgevil, O. ve Budak, G. (2008). İşletmelerin farklılıkların yönetimi anlayışına yaklaşım tarzlarının saptanmasına yönelik bir araştırma. Dokuz Eylül Üniversitesi Sosyal Bilimler Enstitüsü Dergisi, 10(4), 6596.

Sürgevil, O. (2010). Çalı̧̧ma yaşamında farklılıkların yönetimi. Ankara: Nobel Yayıncilik.

Tannenbaum, R., Weschler, I. R. ve Massarık, F (2013). Leadership and organization: A behavioral science approach. USA and Canada: Simultaneously published. ISBN: 978-0-415-65793-8. 
Taşlıyan, M., Hırlak, B. ve Çiftçi, G.E. (2016). Farklılık yönetiminin örgütsel özdeşleşme üzerine etkisi: akademik ve idari personel üzerine bir araştırma. Elektronik Sosyal Bilimler Dergisi, 15 (59), 1339-1359. ISSN:1304-0278. DOI:10.17755/esosder.59968.

Tekin, M. ve Çiçek, E. (2005). İşletmelerde rekabet üstünlüğü sağlamada farklı bir yaklaşım: değer temelli pazarlama. V. Ulusal Üretim Araştırmaları Sempozyumu, 25-27 Kasım, İstanbul Ticaret Üniversitesi, İstanbul.

Thomas, R. R (2010). World class diversity management: A strategic approach. San Francisco: Berreth Koehler Publishers.

Tozkoparan, G. ve Vatansever, Ç. (2011). Farklılıkların yönetimi: insan kaynakları yöneticilerinin farklılık alg1sı üzerine bir odak grup çalışması. Akdeniz İ.I.B.F. Dergisi 21, 89-109.

Usta, Ö. Ç. ve Bayraktar, O. (2017). İşletmelerde farklılıkların yönetimi ve işten ayrılma niyetine etkisi. İş'te Davranış Dergisi Journal of Behavior at Work, 2(2), 68-78.

Uzay, N. (2005). Tekstil ve giyim sektöründe sürdürülebilir rekabet gücü: kayseri tekstil ve giyim sanayiinde uygulama. H. Ü. İ̈BF Dergisi, 23(1), 59-82.

Ülgen, H. ve Mirze, K. S. (2004). İşletmelerde stratejik yönetim. Beta: İstanbul. Yıldızoğlu, E. (1996). Globalleşme ve kriz. İstanbul: Alan.

Yılmaz, E. ve Kurşun, A. T. (2013). Öğretmenlerin örgütsel bağlllıklarının okullardaki farklılık yönetimi anlayışı açısından incelenmesi. Akademik Bakış Dergisi, 38, 1-14.

\section{Kaynakça Bilgisi / Citation Information}

İmadoğlu, T. ve Türk, M. (2019). Farklılıkların yönetiminin işletmelerin rekabet stratejileri üzerindeki etkisine yönelik bir araştırma OPUS-Uluslararası Toplum Araştırmaları Dergisi, 12(18. UİK Özel Sayıs1), 37-72. DOI: 10.26466/opus.584547 